\title{
Kearifan Lokal dalam Cerita Rakyat Nusantara: Upaya Melestarikan Budaya Bangsa ${ }^{1}$
}

\author{
Erli Yetti ${ }^{2}$
}

\begin{abstract}
Abstrak
Sastra lisan merupakan salah satu bentuk produk budaya yang diciptakan dan diwarisi secara lisan dan turun-menurun melalui alat pengingat (memonic devices). Bentuk sastra ini terus hidup dalam tradisinya dan berkembang menyesuaikan perkembangan masyarakatnya. Sastra lisan sangat beragam bentuknya, mulai dari bahasa rakyat, ungkapan tradisional (pepatah dan peribahasa), pertanyaan tradisional (teka-teki), puisi rakyat (pantun, syair, bidal, dll), dan prosa rakyat, mite (myth), legenda, (legend), dan dongeng (folktale), serta nyanyian rakyat. Jenis sastra ini dalam masyarakat Nusantara bisa menjadi identitas karena di dalamnya terkandung pelbagai kearifan lokal (local wisdom). Prosa rakyat yang lebih dikenal dengan cerita rakyat tersebar di seluruh Nusantara. Sebagai kekayaan budaya, melalui cerita rakyat dapat digali berbagai kemajemukan identitas nasional Indonesia. Dalam masa sekarang kearifan lokal bisa menjadi salah satu cara dalam mewujudkan aspek positif arus globalisasi. Kearifan lokal banyak terdapat dalam cerita rakyat seperti cerita Malin Kundang, Bawang Merah Bawang Putih, Sangkuriang, Pulo Kemaro, Anak Durhaka, dan lain sebagainya. Cerita rakyat tersebut mengandung pesan moral seperti sopan santun, saling menyayangi, suka menolong orang lain, dan lain sebagainya. Keanekaragaman cerita daerah inilah kemudian melahirkan apa yang disebut multikulturalisme. Dengan menempatkan kebangsan sebagai benang merah akan terlihat keberagaman budaya etnis dan pluralitas sebagai budaya dalam "kebhineka tunggalikaan".
\end{abstract}

Kata kunci: kearifan lokal, cerita rakyat, pelestarian, multikulturalisme, kebangsaan

\footnotetext{
${ }^{1}$ Pernah disajikan pada Seminar Internsional Bahasa dan Sastra dalam Konteks Kebangsaan (2010)

${ }^{2}$ Pembantu Pimpinan pada Pusat Bahasa Kemendiknas
} 
14| Mabasan - Vol. 5, No. 2, Juli-Desember 2011

\section{Pendahuluan}

Sastra lisan merupakan salah satu bentuk produk budaya yang diciptakan dan diwarisi secara lisan dan turun temurun melalui alat pengingat (memonic devices). Bentuk sastra ini terus hidup dalam tradisinya dan berkembang menyesuaikan perkembangan masyarakatnya. Bentuk sastra lisan sangat beragam, mulai dari sastra rakyat, ungkapan tradisional (pepatah dan peribahasa), pertanyaan tradisional (teka-teki), puisi rakyat (pantun, syair, bidal, dll), dan prosa rakyat, mite (myth), legende (legend), dan dongeng (folktale), serta nyanyian rakyat. Jenis sastra ini dalam masyarakat Nusantara bisa menjadi identitas karena di dalamnya terkandung berbagai kearifan lokal (local wisdom).

Prosa rakyat atau lebih dikenal dengan cerita rakyat adalah cerita yang berasal dari masyarakat dan berkembang dalam masyarakat. Di dalam cerita rakyat tersebut terkandung nilai-nilai positif yang dapat menjadi cermin kehidupan kita dalam bertindak dan bertingkah laku. Melalui cerita rakyat ini pula, kita dapat memberikan nasihat kepada anak kita tanpa menggurui. Namun, tidak dapat kita pungkiri tidak semua cerita rakyat dapat dicerna oleh anak kita.

Dengan tersebarnya cerita rakyat di seluruh Nusantara, penggalian kearifan lokal menjadi penting sebagai upaya untuk tetap melestarikan budaya bangsa dan menjaga identitas bangsa. Cerita rakyat yang tersebar di wilayah Nusantara dipandang memiliki potensi untuk menggali budaya lokal. Kepulauan Indonesia terdiri dari tiga puluh tiga provinsi jelas memiiliki cerita rakyat sangat banyak jumlahnya. Dalam makalah ini penulis membahas cerita yang mewakili daerah Sumatra, Jawa, dan Nusa Tenggara Timur.

Kearifan lokal merupakan salah satu produk budaya. Produk budaya itu dapat berbentuk bendawi (tengible) maupun yang nonbendawi (intengible). Produk budaya ini digunakan sebagai rujukan bagi kehidupan bermasyarakat dan berkomunikasi, baik komunikasi dengan sesama manusia, alam, maupun Tuhan. Melalui kearifan lokal, para pemilik dan penggunanya diharapkan dapat meningkatkan kualitas kehidupan dan selanjutnya dapat memuliakan hidup itu sendiri. Kearifan lokal termasuk tradisi yang masih hidup ada pewarisnya, baik pasif maupun aktif dan seringkali dalam implikasinya dikaitkan dengan nilai moral tentang baik dan buruk. Bagi pelanggar nilai moral tersebut akan dikenai sangsi sosial kultural berupa 1) dituduh sebagai orang yang tidak tahu adat, 2) dihindari dari pergaulan bahkan tidak jarang diasingkan. Hukuman ini masih berlaku dalam beberapa masyarakat adat, seperti di Bali. 
Padanan kata kearifan lokal adalah istilah lokal genius yang berarti "kemampuan lokal atau setempat". Istilah itu pernah dipakai oleh Quarths Wales saat membicarakan masalah kebudayaan Hindu dengan "local culture ability to manage Hindu influence". Artinya, kebudayaan lokal mempunyai kemampuan mengolah pengaruh kebudayaan Hindu. Pada masa itu pengaruh kebudayaan Hindu sangat deras. Masalah itu disampaikan dengan adanya pertemuan antarbudaya.

Dalam pengukuhannya sebagai guru besar di dibidang ilmu Antropologi dan Sejarah Indonesia Kuno di Leiden tahun 1946, FDK Bosch menyampaikan masalah dalam penelitiannya Het Vraastuuk Vande Hindu Colonisatie Van de Archipel (berbicara tentang penyebaran kebudayaan Hindu di kepulauan Indonesia (Ardika, 2001).

Perubahan kebudayaan merupakan suatu fenomena normal dan wajar. Perjalanan sejarah menunjukkan bahwa suatu kebudayaan mampu mengadopsi dan mengadaptasi kebudayaan asing/luar menjadi bagiannya tanpa kehilangan jati diri. Dalam interaksi tersebut kebudayaan suatu etnis akan mengalami proses perubahan berkelanjutan (change and continuity). Unsur kebudayaan yang tidak sesuai dengan zamannya tampaknya ditinggalkan dan digantikan dengan unsur baru.

Unsur kebudayaan yang sulit berubah adalah nilai-nilai spritualitas, yaitu jati diri. Menurut Peter L. Berger (Nashir, 1999:41), agama adalah kanopsi suci untuk menghadapi kekacauan (The scared canopy of chaos). Maksudnya adalah agama adalah langit suci yang teduh melindungi kehidupan. Masyarakat harus kembali pada nilai dasar (basic value) atau prinsip dasar.

Kearifan lokal merupakan nilai-nilai luhur yang terkait dengan nilainilai ketuhanan dalam masyarakat perlu kiranya direvitalisasi untuk membentengi diri dari pengaruh budaya global yang cenderung bersifat materilialistis. Untuk menghadapi kondisi ini, ada konsep-konsep yang berasal dari kekayaan lokal yang patut diangkat dan diperkenalkan kembali. Misalnya, di Bali dikenal konsep tri hita karana yang mengedepankan hubungan yang harmonis dan seimbang antara manusia dengan Tuhan, sesama manusia dan lingkungan alam perlu disosialisasikan dan diejawantahkan dalam kehidupan real.

Pada masyarakat kita, kini muncul berbagai penyakit keterasingan (alienasi). Alienasi ekologis, manusia secara mudah merusak alam dan kekayaan yang terkandung di dalamnya dengan penuh kerakusan dan tanpa menghiraukan 
Mabasan - Vol. 5, No. 2, Juli-Desember 2011

kelangsungan hidup di masa depan. Alienasi etologis, manusia kini mengingkari hakikat dirinya hanya karena memperebutkan materi dan mobilitas kehidupan. Alienasi masyarakat, menunjukkan keretakan dan kerusakan dalam hubungan antarmanusia dan antarkelompok, sehingga lahir disintegrasi sosiaI. Selain itu, muncul pula alienasi kesadaran, yang ditandai oleh hilangnya keseimbangan kemanusiaan karena meletakkan rasio atau akal pikiran sebagai satu-satunya penentu kehidupan, yang menapikan rasa dan akal budi (Nashir 1999:6).

Berbagai keterasingan tersebut di atas sesungguhnya bertentangan dengan ajaran-ajaran luhur atau kearifan lokal yang kita kenaI selama ini baik di tingkat nasional maupun lokaI. Di tingkat nasional kita mengenal istilah gotongroyong, tenggang rasa (tepa salim), dan musyawarah mufakat. Pada tataran lokal kita mengenal bermacam-macam konsep yang maknanya sama. Orang Nias mengatakan Noronga' uchu gawoni, noro' uchu geo, a/isi tafa daya-dcrya, hulu ta farwolowolo (berat sama dipikul, ringan sama dijinjing). Orang Bali berkata segilik seguluk selunglung sebqyantaka (susah ataupun senang kita harus samasama) (Imawan 2004:1).

Sehubungan dengan itu, secara sadar dan terencana perlu kiranya dikembangkan konsep sadar budaya, termasuk revitalisasi kearifan lokal tersebut. Untuk revitalisasi, kita perlu lebih dahulu meneliti dan menggali berbagai kearifan lokal yang ada dalam berbagai etnis. Penggalian itu perlu dilakukan untuk membentengi diri dalam menghadapi gelombang pengaruh budaya global.

Dalam upaya mengadopsi dan mengadaptasi pengaruh kebudayaan luar di era global ini, manusia Indonesia perlu kiranya kembali kepada nilai-nilai dasar atau pokok (basic/principle value) yang berbasis pada nilai moral dan spiritualitas. Nilai-nilai dasar yang bersumber kepada agama serta kearifan lokal merupakan benteng untuk memperkuat pertahanan diri.

Berbagai konsep yang berkaitan dengan falsafah dalam kehidupan tersimpan dalam produk budaya berbagai etnis dalam sastra Nusantara. Sehubungan dengan itu, dalam makalah ini konsep-konsep itu digali dalam produk budaya yang berbentuk cerita rakyat.

\section{Pembahasan}

\subsection{Keartifan Lokal}

Dalam Webster"s New World Dictionary of the American Language (1952:1538) disebutkan bahwa tradisi adalah perlakuan yang turun temurun 
secara lisan dari suatu generasi ke generasi berikutnya, misalnya dalam bentuk cerita, kepercayaan, dan adat kebiasaan. Pewarisan itu dianggap perlu dan sangat penting karena terkandung sari pengalaman generasi terdahulu yang bermanfaat bagi keturunnanya. Atas dasar itu, dapat diterima pernyataan yang dikemukakan oleh Simanjuntak (1970:73)

...tradisi menekankan otoritet generasi tua, yang tidak boleh

dipersoalkan mutunya. Memang tidak ada yang mengikari kegunaan tradisi sebagai pegangan bagi anak dalam perkembangannya karena tradisi itu merupakan kumpulan pengalaman generasi lampau yang dipergunakan dalam mengatur kehidupan bersama.

Dalam kehidupan sehari-hari, manusia tidak dapat hidup tanpa alam dan tanpa tradisi. Seseorang atau masyarakat yang melepaskan diri dari tradisi lama, tidak berarti masyarakat itu akan terbebas dari tradisi. Tradisi lama yang ditinggalkan akan berganti dengan tradisi baru yang berlaku pada masyarakat baru. Dapat pula dikatakan bahwa apa yang disebut dengan avonturisme dimana ada orang dapat hidup tanpa tradisi sama sekali.

Menutrut Kleden (1988: 244-247), tradisi di sini sebagai tiang topang kebudayaan yang harus dibangun, dipertahankan, dan perlu diuji kembali dalam kehidupan yang lebih baru. Ditegaskan pula sebuah tradisi bukan persoalan dapat diterima atau tidak, melainkan untuk dipertimbangkan kembali dan disesuaikan dengan keperluan baru.

Cerita rakyat yang tersebar di seluruh Nusantara sangat banyak jumlahnya. Cerita rakyat tersebut akan bisa bertahan jika kita selalu memperkenalkannya pada anak-anak kita dan sekaligus dapat menumbuhkan kesadaran betapa bangsa kita sendiri begitu kaya akan kisah-kisah rakyat. Kita tidak perlu menghafal cerita tersebut, paling tidak kita masih mengenal cerita rakyat daerah tempat di mana kita tinggal.

Bila kita membaca cerita rakyat, nilai positif yang terkandung di dalamnya dapat dijadikan cermin kehidupan dalam bersikap dan bertingkah laku. Namun, tidak semua cerita rakyat baik dibaca oleh anak kita karena mungkin cerita itu konsumsi orang dewasa. Oleh karena itu, peranan orang tua sangat diharapkan dalam memperkenalkan cerita rakyat tersebut.

Wilayah Indonesia yang memliki tiga puluh tiga provinsi tentu memiliki cerita rakyat yang demikian banyak jumlahnya. Meski demikian, saya tidak akan memaparkan satu persatu, dalam hal ini saya mengambil cerita yang mewakili saja. 
Mabasan - Vol. 5, No. 2, Juli-Desember 2011

Cerita Mundinglaya Dikusuma berasal dari Jawa Barat. Cerita ini mengisahkan seorang pangeran bernama Mundinglaya yang kemudian diangkat menjadi raja ketika Prabu Siliwangi memerintah kerajaan tersebut. Prabu Siliwangi mempunyai dua orang istri, yaitu Dimas Tejamantri dan Nyiman Padmawati. Dari hasil perkawinan keduanya Prabu Siliwangi mendapat anak bernama Pangeran Guru Gantangan dan Mundinglaya. Pangeran Guru Gantangan kemudian menikah dan ia mendapatkan anak bernama Sunten Jaya. Meski sudah memiliki anak, Pangeran Gantangan mengangkat Mundinglaya sebagai anaknya. Guru Gantangan lebih menyayangi Mundinglaya dari Sunten Jaya sebab perbedaan karakter keduanya sangat jauh. Mundinglaya memilik wajah rupawan dan sifatnya baik dan santun sedangkan Sunten Jaya memiliki sifat angkuh dan manja. Oleh karena merasa iri, Mundinglaya dijebloskan ke penjara oleh Sunten Jaya dengan dalih Mundinglaya telah mengganggu kehormatan wanita. Keputusan itu membuat Pajajaran terpecah dua, ada yang pro dan ada yang kontra. Keadaan itu telah membuat perpecahan dan permusuhan antarsaudara.

Pada situasi yang gawat, Nyimas Padmawati bermimpi melihat tujuh guriang di puncak gunung. Salah seorang dari mereka membawa Layang Salaka Domas. Mereka juga berkata, negeri itu akan aman bila yang mengambilnya seorang ksatria. Setelah permaisuri menceritakan kepada suaminya, Prabu Siliwangi kemudian meminta Guru Gantangan untuk melepaskan Pangeran Mundinglaya. Mundinglaya pun kemudian ditugasi untuk mengambil Layang Salaka Domas. Bagi Mundinglaya tugas ini merupakan pembebasan dirinya sedang bagi Sunten Jaya, saudara tirinya situasi itu merupakan cara menyingkirkan musuhnya karena pamannya akan dibunuh oleh Jonggrang Kalapitung. Selama seminggu Mundinglaya diajarkan ilmu perang oleh patih Lengser. Dalam perjalanan ke Jabaning Langit, Mundinglaya lebih banyak minta petunjuk dan berpasrah diri pada Tuhan. Ketika menuju Tanjung Barat, ia bertemu dengan Dewi Kania atau Dewi Kinawati. Setelah melalui perjuangan cukup berat melawan para guriang, mundinglaya dapat membawa pulang Layang Salaka Domas itu. Mundinglaya kemudian sampai di Pajajaran. Prabu Siliwangi kemudian menobatkan Mundinglaya sebagai Raja Pajajaran menggantikannya dengan gelar Mundinglaya Dikusumah. Tidak lama berselang, ia menikah dengan Dewi Kinawati.

Apa yang dipaparkan cerita di atas, kita dapat melihat beberapa kearifan lokal terdapat dalam cerita tersebut antara lain, kejujuran, tidak tamak, sabar, 
berserah diri kepada Tuhan Yang Maha Esa, dan membela Negara. Nilai taat dan berserah diri pada Yang Maha Kuasa ini dapat digolongkan pada hubungan manusia dengan Tuhan. Kita sebagai manusia hidup di dunia tidak lepas dari pertolongan Tuhan Yang Maha Esa. Sebagai manusia kita dapat berusaha, tetapi keputusan tetap pada Tuhan. Di dalam cerita Mundinglaya Diksumah ini kita dapat melihat bagaimana kekuatan Yang Maha Kuasa saat itu. Ketika Mundinglaya sedang berjuang untuk mendapatkan jimat Layang Saloka Domas yang ditugaskan Prabu Siliwangi tidak sedikit cobaan yang dihadapinya termasuk raksasa Jonggrang Kalipitung. Dengan segala ilmu dan kekuatan doanya kepada Allah, Mundinglaya akhirnya dapat terlepas dari raksasa tersebut. Lepas dari hadangan raksasa, kini Mundinglaya berhadapan dengan para guriang si penjaga jimat tersebut. Untuk dapat memiliki Layang Saloka Domas, Mundinglaya harus bertempur terebih dahulu melawan guriang. Awalnya Mundinglaya kalah bahkan mati, tetapi berkat bantuan makhluk supranatural, Mundinglaya hidup kembali dan berhasil mendapatkan Layang Saloka Domas.

Nilai membela dan cinta tanah air dapat digolongkan dalam hubungan manusia dengan orang lain. Di sini Mundinglaya mau mengorbankan dirinya untuk negerinya. Tawaran Pangeran Prabu Siliwangi kepada Mundinglaya bukanlah hal yang kecil karena Mundinglaya harus siap mengorbankan nyawanya. Akan tetapi, ia berpikir alangkah baiknya dapat melakukan perjalananan itu untuk mendapatkan jimat Layang Saloka Domas sesuai mimpi permaisuri Nyimas Padmawati. Seperti yang kita ketahui selama ini, Pajajaran terpecah menjadi dua karena ada yang berpihak kepada Guru Gantangan dan ada yang berpihak kepada dirinya. Salah satu cara menyatukan dua kutub itu adalah jimat Layang Saloka Domas. Setelah Mundinglaya berhasil mendapatkannya, rakyat bersorak dan negerinya bersatu. Mundinglaya diangkat sebagai pemimpin. Sedang Gurung Gantangan bersifat jahat diusir dari negeri itu.

Nilai kejujuran, tidak tamak, dan sabar dapat digolongkan dalam hubungan manusia dengan diri sendiri. Sifat yang dimiliki Mundinglaya sangat bersahaja. Ia selalu jujur dan sabar terhadap apa yang menimpanya. Ketika ia dipenjarakan oleh Gurung Gantangan dengan tuduhan menggagu kehormatan wanita, Mundinglaya menerima saja. Akan tetapi, berkat mimpi permaisuri, Mundinglaya akhirnya keluar dari penjara. Sifat Guru Gantangan bertolak belakang dengan Mundinglaya. Ia adalah orang yang memiliki rasa iri hati dan 


\section{0| Mabasan - Vol. 5, No. 2, Juli-Desember 2011}

tidak mau melihat kelebihan orang lain. Ia dengan sengaja menfitnah Mundinglaya jika tidak dapat menyelesaikan tugasnya sesuai waktu yang disediakan. Keadaan itu pula yang mendorong Mundinglaya harus berhasil dan akan berkorban demi ibunya.

Cerita Asal Danau Toba berasal dari Sumatra Utara menceritakan tentang kehidupan seorang petani tua. Petani ini sangat rajin bekerja meski tidak mempunyai ladang yang luas. Desa itu terkenal dengan kemakmurannya. Banyak hasil padi dan sawah yang dihasilkannya. Pada saat petani ingin memakan ikan pancingannya, dari mulut ikan keluar suara yang mengatakan kalau dirinya adalah manusia yang dahulu mendapat kutukan sang dewata. Ikan tersebut kemudian berubah menjadi putri cantik kemudian menikah dengan petani tersebut. Setelah itu mereka mempunyai seorang anak lelaki yang dalam pertumbuhannya ia menjadi anak nakal. Anak ini tidak pernah menuruti perintah dan anjuran bapaknya. Sampai suatu hari bapaknya sudah habis kesabaran dengan anaknya lalu tidak sengaja berucap dasar anak ikan. Karena istrinya adalah jelamaan dari seekor ikan maka tidak lama anak dan istrinya tiba-tiba hilang dan datanglah air bah seperti danau. Anak dan istrinya sudah berada di danau itu dan tempat itu sampai sekarang dikenal Danau Toba.

Dari cerita itu, ditemukan kearifan lokal kemakmuran, bekerja keras, tidak patuh pada orang tua, percaya pada Tuhan Yang Maha Esa. Nilai kemakmuran di sini erat hubungannya antara manusia dengan Alam. Alam ciptaan Tuhan harus dijaga dan dirawat seperti halnya dengan alam Danau Toba. Negeri itu tidak saja memiliki danau yang indah, tetapi juga tanahnya subur sehingga tanaman seperti ladang dan berbagai tanaman dapat tumbuh dengan baik.

Nilai percaya pada Tuhan Yang Mahakuasa dapat dihubungkan antara manusia dengan Tuhan. Sebagai seorang bapak, petani ini seharusnya memilki kesabaran terhadap anaknya yang dapat digolongkan anak nakal. Karena kelelahan bekerja, petani ini tidak dapat mengendalikan emosi melihat anaknya tidak mau mengantar makanan ke ladang. Ia hanya bermain-main saja di rumah. Kemarahan yang sudah sampai puncak akhirnya membawa petaka. Ucapan berupa kutukan di dengar oleh Tuhan sehingga ia harus kehilangan anak dan istri.

Nilai patuh kepada orang tua dapat digolongkan dalam hubungan manusia dengan orang lain. Anak petani dalam cerita di atas termasuk anak nakal. Ia tidak sedikit pun mau membantu orang tuanya yang bekerja sehari-hari 
mencari nafkah. Apabila bapaknya meminta bantuan, pasti dibantah. Oleh karena itu, Tuhan mendengarkan kutukan bapaknya karena sudah tidak tahan dengan perilaku si anak.

Nilai hubungan manusia dengan diri sendiri dapat dilihat dari perbuatan petani. Sebagai orang tua seharusnya si bapak lebih banyak memiliki kesabaran dan kearifan terhadap anaknya. Anak yang nakal tadi seharusnya dididik secara pelan-pelan dan bukan dengan kekasaran. Oleh karena bapak tidak dapat mengendalikan emosi akhirnya ia kehilangan harta yang paling berharga yaitu anak dan istri.

Cerita Legenda Bukit Fafinesu berasal dari NTT, mengisahkan tiga orang anak yatim piatu masing-masing si sulung bernama Saku, si tengah bernama Abatan, dan yang bungsu bernama Seko. Mereka bertiga merupakan anak yatim miskin karena orang tuanya tidak meninggalkan barang apa pun. Adiknya yang paling kecil selalu menangis menanyakan dimana kedua orang tuanya dan Saku selalu menjelaskan kepada adiknya itu. Saku sebagai anak tertua selalu bertanggung jawab kepada kedua adiknya. Hanya saja untuk soal makan ketiga anak itu terlantar. Biasanya ibu bapaknya selalu membawa daging dendeng babi atau rusa sepulang dari bekerja, tapi sekarang makanan itu sudah tidak dapat lagi dirasakannya. Ayahnya meninggal dalam sebuah kecelakaan ketika berburu babi. Kepalanya tertindih batu di sebuah bukit hingga meninggal, sedangkan ibunya meninggal ketika melahirkan si Seko. Dua tahun kemudian, meninggal pula nenek yang mengasuh mereka. Suatu hari Saku tidak dapat memejamkan mata. Ia keluar dari pondoknya dan memainkan suling. Tidak terasa air matanya meleleh di pipi. Ia teringat akan ayah ibunya yang sudah tiada. Ternyata, kesedihan Saku tidak saja jengkrik yang mendengarkan, melainkan ayah ibunya juga mendengar. Entah dari mana datang suara yang pasti suara ayah dan ibunya yang mengatakan kalau mereka sangat merindukan anak-anaknya. Untuk itu, sebelum matahari muncul di ufuk timur, ibunya meminta adanya pertemuan antara mereka di balik bukit tempat kecelakaan ayahnya dan ibunya meminta Saku membawa ayam jantan. Tepat pada waktu yang ditentukan, mereka bertemu dan darah ayam jantan merah yang dibawa Saku menetes di atas batu untuk dijadikan korban. Keluarga kecil itu pun melepas rindu. Ketika matahari muncul, tiba-tiba kedua orang tuanya menghilang dan pintu goa tiba-tiba terbuka. Ternyata di dalamnya telah menunggu dua ekor babi yang siap dibawa pulang. Sejak peristiwa bukit itu lebih dikenal dengan Bukit Fafinesu. 
Dari cerita di atas, terdapat nilai kasih sayang, tanggung jawab, dan kekuasaan Nilai kekuasaan dapat digolongkan antara hubungan manusia dengan Tuhan. Dalam cerita ini kedua orang tua anak yatim yang telah meninggal dapat bertemu kembali dengan anak-anaknya walaupun hanya melalui suara saja. Meski kisahnya dari penjelmaan, namun di sini tetap ada campur tangan Tuhan. Segala sesuatu tidak akan terjadi tanpa kekuasaan Yang Mahakuasa.

Nilai kasih sayang dapat digolongkan antara manusia dengan manusia lain. Hubungan antara anak dan orang tua yang sudah tiada tetap terjalin meski sudah tiada. Kesedihan dan kegelisahan yang dirasakan ketiga anaknya juga dapat dirasakan almarhum orang tuanya. Hal itu terbukti ketika Saku sedang memainkan seruling tiba-tiba muncul suara ayahnya yang mengatakan untuk mengadakan pertemuan di bukit Batu Fafinesu. Dalam pertemuan itu, ibu dan anak saling berbicara melepaskan kerinduannya meski melalui suara. Nilai kasih sayang juga dapat dilihat dari hubungan persaudaraan antara ketiga bersaudara begitu pula nilai tanggung jawab. Sebagai anak sulung, Saku sangat bertanggung jawab kepada kedua adiknya. Ia selalu menjaga, merawat, dan memberi makan kedua adiknya. Meski kehidupannya susah, mereka selalu saling menyayangi.

\subsection{Multikulturalisme dan Kebangsaan}

Dari segi geo-politik, kepulauan Indonesia terdiri dari beragam budaya yang dihuni oleh berbagai suku masing-masing memiliki agama dan latar belakang yang berbeda. Melalui proses historis, budaya lokal yang dimiliki masing-masing etnis mengadakan kontak budaya politik dalam bentuk ideologi kekuasaan seperti yang dialami Kerajaan Majapahit dan Sriwijaya. Kebudayaan politik seperti ini memperkuat pertumbuhan budaya lokal yang dipengaruhi oleh unsur budaya yang lebih kuat, yakni budaya Melayu yang bernafaskan Islam dan budaya "Jawa Majapahit" bernafaskan Hindu. Tradisi luar ini akan berpengaruh pada tradisi kecil dan akan melahirkan budaya daerah (lokal) dan memiliki akar budaya yang kuat dari masing-masing daerah. Keanekaragaman budaya daerah inilah yang kemudian melahirkan mulkulturalisme, yaitu pandangan adanya kemajemukan budaya yang dimiliki suatu bangsa. Budaya daerah yang mendasari budaya "Nusantara" kemudian berkembang menjadi Kebudayaan Nasional. 
Menurut E.B. Tylor, budaya itu mengandung pengertian yang luas dan kompleks, menyangkut pengetahuan, kepercayaan, seni, hukum, moral, adat istiadat, tradisi, dan sebagainya hingga melahirkan kebudayaan sebagai suatu sistem, atau serangkain nilai yang melandasi pada orientasi, sikap, dan tingkah laku.

Di dalam cerita rakyat Nusantara ini, kita dapat melihat apa yang dinamakan multikulturalisme itu, yaitu cerita rakyat yang tersebar di berbagai wilayah Indonesia. Cerita rakyat tersebut dilatarbelakangi dengan bahasa dan budaya yang berbeda-beda. Melalui pendekatan budaya politik tentunya akan dapat terwujud nasionalisme sebagai kebudayaan Nasional (budaya bangsa) dan akan menjadi perekat bangsa dalam kebinekatunggalikaan. Kebudayaan Nasional sebagai budaya bangsa memberi peluang untuk berkembangnya budaya daerah yang multikultularisme dan tentu akan dapat dilestarikan dalam arti dikembangkan dan dipelihara sesuai dengan teknologi, seni, dan pengetahuan dalam era globalisasi.

\section{Simpulan}

Dalam mengadopsi dan mengadaptasi pengaruh budaya luar di era globalisasi, perlu kiranya kita kembali melihat budaya lokal (daerah). Begitu pula halnya dalam cerita rakyat Nusantara yang tersebar di kepulauan Indonesia. Cerita yang tidak terhitung jumlahnya itu mengandung kearifan lokal, seperti cerita rakyat Danau Toba, Bukit Fafinesu, dan Mundingkaya Dikusumah. Di dalam ketiga cerita rakyat yang dijadikan contoh ini terkandung nilai moral, seperti tanggung jawab, patuh kepada orang tua, kasih sayang, kejujuran, dan lain sebagainya. Nilai ini kemudian dikaitkan antara hubungan manusia dengan Tuhan, hubungan manusia dengan diri sendiri, hubungan manusia dengan manusia, dan hubungan manusia dengan alam. Dengan adanya keberagaman cerita rakyat Nusantara ini terbentuklah multikulturalisme dalam "kebhinekatunggalikaan" yang terus dapat dilestarikan dan dipelihara sebagai budaya bangsa Indonesia. 
24| Mabasan - Vol. 5, No. 2, Juli-Desember 2011

\section{Daftar Pustaka}

Ayat Rohaedi. 1986. Kepribadian Budaya Bangsa (Lokal Genius). Pustaka Jaya, Jakarta.

Ardhana, I Gst. Gede. 2005. "Kearifan Lokal dan Katahanan Budaya Bali" dalam Kompetisi Budaya dalam Globalisasi (ed. Kusumanjali). Bali: FS Unud.

Ardhika, I Wayan. 2005. "Strategi Bali Mempertahankan Kearifan Lokal di Era Global" dalam Komperisi Budaya dalam Globalisasi (ed. Kusumanjali). Bali: FS Unud.

"Bhineka Tunggal Ika" dalam /www.indonesiamedia.com/2004/05/early /budaya/budaya-0504-bhineka.htm, didownlod 7/15/04

Damono, Sapardi Djoko. 1984. Sosiologi Sastra Suatu Pengantar. Jakarta: Pusat Pembinaan dan Pengembangan Bahasa, Departemen Pendidikan dan Kebudayaan.

Fadiela, Nur. 2010. Kumpuklan Cerita Rakyat Nusantara. Penerbit: Genhius Publhiser.

Koentjaraningrat. 1984. Kebudayaan Mentalitas dan Pembangunan. Jakarta: PT Gramedia.

Neonbasu SVD, Gregor, et al. 1996. Cerita Rakyat Dari Nusa Tenggara Timur. Penerbit: Grasindo.

Simanjuntak, IP. 1970. “Pola-Pola Pendidikan Kepribadian”. Jakarta:Ganaco.

Wellek, Rene dan Austin Warren. 1989. Teori Kesusastraan. Diterjemahkan oleh Melani Budianta dari Theory of The Literature. Jakarta: Gramedia. 